\title{
Refugee health care funding in Canada
}

\section{History, current state, and future directions}

\author{
Caroline Piccininni, Michelle Kwong
}

\begin{abstract}
Due to a steady rise in the number of refugees accepted by Canada in recent years, the need for government funding to cover the health care needs of this population has similarly increased. Despite this increased need, government funding via the Interim Federal Health Program (IFHP) was cut dramatically in 2012 by the Conservative government. In 2016, the Liberal government restored full refugee health care coverage. This article provides an overview of refugee health care funding decisions in Canada over the past decade, and explores the impact that such decisions have on the health outcomes of this population. Furthermore, this article compares and contrasts refugee health care funding in Canada with that in other world regions with high refugee influx. Key potential areas for funding improvement are identified.
\end{abstract}

\section{INTRODUCTION}

Resettling refugees is the transfer of refugees from an asylum country to another country for permanent settlement. It is a delicate, emotionally charged, and highly political process. When citizens lose faith in their government's refugee policies, there arises potential for anti-immigrant backlashes that can reverse decades of progress. Over the past decade, the number of refugees accepted into Canada has been rising steadily, soaring from 10365 in 2013 to a high of 50385 in 2017, undoubtedly reflecting recent changes in our country's political landscape. ${ }^{1}$ Our refugee system must strike an economically sound balance between our global responsibility to provide protection to those fleeing persecution and our sovereign duty to ensure that our already overburdened welfare system is not misused.

\section{HISTORY OF REFUGEE HEALTH CARE FUNDING IN CANADA}

Once on Canadian soil, resettled refugees, inland refugee claimants awaiting decisions, and successful protected persons are eligible to receive basic health benefits under the Interim Federal Health Program (IFHP). Regardless of refugee status or country of origin, all individuals have historically received uniform coverage similar to that provided by provincial and territorial insurance, including basic and supplemental care, as well as prescription drug coverage. Coverage is terminated when recipients become eligible for provincial or territorial health insurance, or when a removal order comes into effect. In the midst of immigration security reforms in 2012, the Conservative Party of Canada cut funding to the
IFHP by Can $\$ 12$ million, forecasting that this policy change would save citizens an estimated Can $\$ 20$ million annually in costs. ${ }^{2}$ Under this policy, level of coverage provided was based on categories of refugee status: resettled refugees and protected persons retained full coverage; however, active claimants, failed claimants, and claimants originating from countries in which persecution is deemed unlikely could access emergency and preventative care only if the condition posed a public health risk. ${ }^{3}$ Health care professionals across the country met this decision with righteous outrage, while populist voices among working class citizens supported a policy that put Canadians before migrants of uncertain status. When the Federal Court of Canada ruled the IFHP revisions as a violation of the Canadian Charter of Rights and Freedoms constituting "cruel and unusual treatment" of an already vulnerable population, the Liberal government restored full coverage to all refugees by April 2016. ${ }^{4}$

\section{HEALTH ECONOMICS OF REFUGEE HEALTH CARE FUNDING IN CANADA}

A health economics analysis of the 2012 policy and its subsequent reversal sheds light on how Canada might approach health care funding of refugees in the future. From 2012 to 2016, it is estimated that the federal government saved Can\$96 164 861 , or an average of approximately Can $\$ 24$ million per year, in health coverage for refugees. ${ }^{5}$ However, some costs of caring for uninsured refugee claimants were downloaded to the provinces and territories. With IFHP coverage refocused from primary to urgent care, refugee claimants arrived in emergency rooms with exacerbated conditions, such as diabetes and mental health conditions, that could have been more cost-effectively treated at earlier stages. ${ }^{6}$ In fact, the admission rates for refugee children at Sick Kids Hospital in Toronto nearly doubled. ${ }^{78}$ As a result of their ethical responsibilities to treat patients in emergencies, many public hospitals across the country absorbed the costs of providing care for uninsured refugee themselves. ${ }^{10}$ The University Health Network in Toronto, for instance, reported an unpaid service debt totalling greater than Can $\$ 800000$ for uninsured emergency services alone due to the IFHP reforms. ${ }^{11}$ To cover gaps in care left by the IFHP in Ontario, where approximately $46 \%$ the country's refugee claimants live, the Ontario Temporary Health Program ran from 2014 to 2016, reimbursing up to Can $\$ 1.2$ million annually for services for refugee claimants. ${ }^{12}$ Quebec covered basic care for refugee claimants, with a cost likely similar to Ontario's as it houses the second largest number of refugee claimants. Other provinces and territories did not establish formal insurance programs. ${ }^{12}$

Examining the period in which the IFHP reforms lasted purely through a health economics lens, the financial costs downloaded 
to provincial governments do not amount to the cost savings on the federal level. With that being said, for refugee claimants who eventually became permanent residents and Canadian citizens, the long-term costs of adverse health outcomes on social assistance usage, employment, and successful integration into Canadian society are difficult to quantify but undoubtedly significant. Ultimately, the decision to restore full coverage for refugees regardless of status was one driven not by health economics, but one inspired by the moral fabric of the Canadian health care system which we largely fight to maintain.

\section{LESSONS FROM OTHER REFUGEE HEALTH CARE PROGRAMS}

A 2018 paper by Spiegel et al. emphasized that the primary goal of refugee health care funding should be integration under national insurance systems, wherever they exist and are functioning. ${ }^{14}$ This is most easily done in nations that have universal health coverage schemes, such as Canada. ${ }^{14}$ Although the Liberal government's 2016 reinstitution of full IFHP coverage was beneficial for both health care access and the overall health of refugees, significant gaps in service provision remain-particularly in the areas of mental health, women's health, and obstetrical care. ${ }^{15}$ An important principle of refugee health care is that refugees should both have access to and be provided a similar level of services to an average citizen of that nation. ${ }^{16}$ Although this is a theoretical goal of Canada's IFHP, in reality, this is not always the case.

Looking to the European region, similar evidence of poorer perinatal and mental health outcomes among refugees has also been documented. ${ }^{15}$ Of note, these poorer outcomes were not consistent across all subgroups of refugees. Regarding perinatal health, the World Health Organization (WHO) recommends providing full health coverage for all pregnant women, regardless of immigration status. ${ }^{17}$ Prenatal care is widely accepted as costeffective, and some of the earliest research on this topic estimated that every US\$1.00 spent on obstetrical care resulted in savings of US\$2.02 in newborn care in the first 60 days of life. ${ }^{18}$ Routine prenatal care is recommended for all pregnant women in Canada, which means that it should be funded and accessible to all as well. In terms of mental health, the WHO has suggested that longer appointment times for refugees and provision of interpretation services may be beneficial. ${ }^{19}$ Achieving longer appointment times, especially within Canada's overburdened mental health system, will continue to pose a challenge. Significant change is required in physician reimbursement for longer appointments, and expansion of the number of professionals who can provide such services is needed. For medical interpretation services, funding under the IFHP is limited and insufficient in its current state. The estimated cost of interpretation services starts at Can $\$ 1.50 /$ minute. $^{19}$ Without adequate interpretation services, patients are at risk for misdiagnosis, unnecessary tests, improper informed consent, and violations of confidentiality.

Some Canadian health care providers have reported reluctance to see patients covered under IFHP due to the perceived complexity of the program, including its cumbersome registration process, lack of clarity regarding which services are covered, and long reimbursement times. ${ }^{20}$ This represents another potential area for improvement, and one in which provider education models from other countries may be adapted. For example, some regions in Australia have created Refugee and Asylum Seeker Networks where information can be provided to health care providers, refugee service providers outside the health care sector, sponsors, and refugees themselves. ${ }^{21}$ Such all-encompassing education initiatives ensure that all groups have the same understanding of what types of coverage and services are available, and are quickly informed when a change occurs.

\section{CONCLUSION}

Canada's system for refugee health coverage has endured a number of changes over the past decade. The drastic reduction of refugee health coverage by the federal government in 2012, followed by its ultimate restoration in 2016, substantially impacted costs, access, and health outcomes for Canada's refugee population. Currently, key areas for investment of funds include improving maternal and mental health care, expanding medical interpretation services, and provider education regarding both the IFHP and the specific health needs of refugee populations. Decisions regarding the reallocation of funds should reflect the WHO's recommendations, and should be informed by successful models from other countries, many of which have much larger refugee populations than Canada.

\section{REFERENCES}

1. Canada.ca [Internet]. Ottawa: Government of Canada; 2018. Asylum claimants processed by Canadian Border Services Agency (CBSA) and Immigration, Refugees and Citizenship Canada (IRCC) Offices, January 2011-October 2018; 2018 [cited 2018 Nov 27]. Available from: https://www.canada.ca/en/immigration-refugees-citizenship/ services/refugees/asylum-claims/processed-claims.html

2. Report on plans and priorities, Citizenship and Immigration Canada, 2010-2011 [Internet]. Ottawa: Treasury Board of Canada Secretariat; 2010 [cited 2018 Nov 27]. Available from: http://publications.gc.ca/ pub?id=9.567181\&sl $=0$

3. Jackson S. The new Interim Federal Health Program: how reduced coverage adversely affects refugee claimants' employment [Internet]. Toronto: Ryerson Centre for Immigration \& Settlement, Ryerson University; 2012 Nov [cited 2018 Nov 27]. Available from: https:// www.ryerson.ca/content/dam/rcis/documents/RCIS_Research Brief_No_l.pdf

4. Wyld A. Liberal government fully restores refugee healthcare program. Canadian Broadcasting Corporation [Internet]. $2016 \mathrm{Feb}$ 19 [cited 2018 Nov 26];Politics:[about 5 p.]. Available from: https:// www.cbc.ca/news/politics/mcallum-philpott-interim-federal-healthprogram-refugees-1.3453397

5. Authorities and expenditures by program for 2012-13 to 2016-17 [Internet]. Ottawa: Government of Canada; 2017 Oct 12 [cited 2018 Nov 26]. Available from: https://www.canada.ca/en/treasury-boardsecretariat/services/planned-government-spending/budgetsexpenditures/authorities-expenditures-program-2017.html

6. Exploring the cost effectiveness of early intervention and prevention 
[Internet]. London (UK): British Medical Association; 2017 [cited 2018 Nov 27]. Available from: https://www.bma.org.uk/-/media/files/ pdfs/collective\%20voice/policy\%20research/public\%20and\%20 population $\% 20$ health/exploring-the-cost-of-early-intervention-illhealth-prevention.pdf?la=en

7. Antonipillai V, Baumann A, Hunter A, et al. Impacts of the Interim Federal Health Program reforms: a stakeholder analysis of barriers to healthcare access and provision for refugees. Can J Public Health. 2017 Nov;108(4):e435-41. https://doi.org/10.17269/cjph.108.5553

8. Bakewell F, Addleman S, Dickinson G, et al. Use of the emergency department by refugees under the Interim Federal Health Program: a health records review. PLoS One. 2018 May;13(5):e0197282. https:// doi.org/10.1371/journal.pone.0197282

9. Evans A, Caudarella A, Ratnapalan S, et al. The cost and impact of the Interim Federal Health Program cuts of child refugees in Canada. PLoS One. 2014 May;9(5):e96902. https://doi.org/10.1371/journal. pone.0096902

10. Keung N. Ontario hospitals absorb health costs to treat refugees. The Star [Internet]. 2018 Jun 8 [cited 2018 Nov 26];Immigration:[about 2 p.]. Available from: https://www.thestar.com/news/ immigration/2013/06/08/ontario_hospitals_absorb_health_costs_to_ treat_refugees.html

11. Holtzer E, Moore-Dean A, Srikanthan A, et al. Reforming refugee health care in Canada: exploring the use of policy tools. Healthc Policy. 2017 May;12(4):46-55. https://doi.org/10.12927/hcpol.2017.25099

12. 2015-16 published plans and 2014-2015 annual report [Internet]. Toronto: Ontario Ministry of Health and Long-Term Care; 2016 [cited 2018 Nov 28]. Available from: http://www.health.gov.on.ca/en/ common/ministry/publications/plans/ppar15/\#2.1

13. Refugee health survey by province and by category [Internet]. Montreal (QC): Canadian Council for Refugees; 2015 Feb [cited 2018 Nov 28]. Available from: http://ccrweb.ca/sites/ccrweb.ca/files/ccrrefugee-health-survey-public.pdf

14. Spiegel P, Chanis R, Trujillo A. Innovative health financing for refugees. BMC Med. 2018 Jun;16(1):90. https://doi.org/10.1186/s12916018-1068-9

15. UNHCR global strategy for public health 2014-2018 [Internet]. Geneva: United Nations High Commissioner for Refugees; 2014 [cited 2018 Nov 27]. Available from: http://www.unhcr.org/530f12d26.pdf

16. Khanlou N, Haque N, Skinner A, et al. Scoping review on maternal health among immigrant and refugee women in Canada: prenatal, intrapartum, and postnatal care. J Pregnancy. 2017;2017:8783294. https://doi.org/10.1155/2017/8783294

17. Bradby H, Humphris R, Newall D, et al. Public health aspects of migrant health: a review of the evidence on health status for refugees and asylum seekers in the European region (Health Evidence Network Synthesis Report 44) [Internet]. Copenhagen: WHO Regional Office for Europe; 2015 [cited 2018 Nov 26]. Available from: http://www.euro. who.int/_data/assets/pdf_file/0004/289246/WHO-HEN-Report-A52-Refugees_FINAL.pdf

18. Buescher PA, Roth MS, Williams D, et al. An evaluation of the impact of maternity care programs on the Medicaid birth outcomes in North Carolina. Am J Public Health. 1991 Dec;81(12):1625-9. https://doi. org/10.2105/ajph.81.12.1625

19. Bowen S. Language barriers in access to health care [Internet]. Ottawa: Health Canada. 2001 Nov [cited 2018 Nov 28]. Available from: https:// www.canada.ca/content/dam/hc-sc/migration/hc-sc/hcs-sss/alt formats/hpb-dgps/pdf/pubs/2001-lang-acces/2001-lang-acces-eng. pdf
20. Chen YY, Liew JC. Refugees once again have full coverage, but some practitioners still don't know that. Canadian Broadcasting Corporation [Internet]. 2017 May 9 [cited 2018 Nov 26];Opinion:[about 4 p.]. Available from: https://www.cbc.ca/news/opinion/refugee-healthcare-1.4105120

21. Davidson N, Skull S, Chaney G, et al. Comprehensive health assessment for newly arrived refugee children in Australia. J Paediatr Child Health. 2004 Sep;40(9-10):562-8. https://doi.org/10.1111/j.1440$\underline{1754.2004 .00465 . x}$ 